\title{
Perception of Women Executives towards Balancing their Work Life and Personal Life
}

\author{
Upasna Joshi Sethi \\ Associate Professor \\ Punjabi University Regional Centre for Information Technology \& Management, Mohali \\ Email: upasna_sethi@yahoo.com
}

Doi:10.5296/ijld.v5i1.6918ＵRL: http://dx.doi.org/10.5296/ijld.v5i1.6918

\begin{abstract}
The present study is aimed at investigating the perception of women employees working in Public sector banks and Private sector banks towards the factors that support to achieve better work life balance. A field based survey was conducted to collect quantitative data from 500 female bank employees working in Public and Private Sector banks of North India. The data was collected by questionnaire using five point likert scale questions to comparatively analyze the perception of the employees towards Family Support and Organisational Support. Mean, Standard deviation and One way ANOVA has been used to comparatively analyse the factors and to examine the factors that show the significant difference related to their demographic profiles. The result shows that Family Support and Organisational Support plays an important role in maintaining work life balance of women employees despite of their different demographic profiles.
\end{abstract}

\section{Keywords: Work life balance, Family Support, Organisational Support}

\section{Introduction:}

Work-life balance, in its broadest sense, is defined as a satisfactory level of involvement or 'fit' between the multiple roles in a person's life (Hudson, 2005). According to Clayton (2005) and Matuska and Charles (2009), a positive correlation between work-life balance and increased organizational performance is clear because of job satisfaction among workers. Work-life balance does not imply striking an equal balance, but rather simply helps to schedule work activities and family commitments in a realistic and rewarding arrangement for the two fundamental needs (Valcour, 2007). Work life balance is a state where an individual manages real or potential conflict between different demands on his or her time and energy in a way that satisfies his or her needs for well-being and self-fulfillment (Clutterbuck, 2003).

Three indicators have been suggested to maintain a fulfilled life and fulfill organizational commitments, productivity and development. First is work related factors causing problems in work life imbalance due to excessive work load, more pressure, excessive working hours. Second related to outside the work that includes social influence, families, friends, dependent responsibilities. Third are the factors that includes awareness about the methods and policies to manage this work life imbalance (Guest, 2002)

Imbalance in work and life means that the two phases of responsibilities are not fulfilling. The more or less in one phase may lead to disturbance in another also which affect both the work life and personal of an employee. Work stress and work life imbalance are correlated with workaholism regardless of gender (Aziz and Cunningham, 2008). There are different causes of imbalance in work life. They are:

- Competition

- Individual Career ambitions

- Global Economy

- Longer Working hours 
- Attention demanded by Family

\section{Material and Methods:}

The current study is a comparative study of work life balance among women employees working in Public and private sector banks. A field investigation survey method has been adopted with the help of questionnaire. For the study, a sample of 500 women respondents, 250 respondents each from public and private sector banks by using stratified sampling was collected from the North India. The questionnaire consisted of 5 point Likert scale to find out the perception of the Public sector banks and Private sector banks employees towards the factors related to Family Support and Organisational Support that helps to maintain work life balance.

For the analysis, Frequency, Standard deviation are used and to examine the factors that shows the significant difference among both the banks related to the demographic profile, One way ANOVA has been used by SPSS 16.0 software.

\section{Theoretical Background:}

Work life balance is the art of balancing the career and work life in a way to achieve the goals and fulfilling all the responsibilities. Work life balance is required both for the male and female employees. Due to changing trend in the employment sector, more females are working outside than before. Women are getting career oriented and want to achieve their goals that they are dreaming from years. But this is always a question that why women can't have it all? Why women avoid taking higher post? In comparison to men, women have to face many responsibilities at the family level. They are dependent upon the family from the support to work outside. Various studies have been conducted in this regard and it was concluded that excessive work load at family level, dependent's responsibilities, child care, family pattern are some of the problems that are faced by the women employees to work in an organization. Women who are married have more responsibilities than single, married women living in the nuclear families don't get any support from the elders and hence it is troublesome for them to work. In a published report by Sunita Natti in 2013 on financial sector banking on women, many examples are listed that showed the increasing participation of women in the banking sector. For past few years, some banks are heading by women on the top position. The country's largest and oldest bank announced the appointment of Arudhati Bhattacharya as its first Managing Director, who started her career in 1977 with SBI as a direct recruit officer. Subhalakshmi Panse, chairperson-cum- managing director of Allahabad bank stated that women started joining banking sector in late $70 \mathrm{~s}$ and at clerical levels. Due to career progression, industry is to have more women at the top in the coming years who will be the leaders and role models for others. Panse herself started her career in 1976 with Bank of Maharashtra. Tyani Vakil was the first women to head the top position in 1996 of EXIM Bank. After her, Ranjana Kumar was appointed as CMD of Indian Bank, which was loss making bank at that time. She turnaround the loss making bank into a profitable bank with her superior leadership skills. Banking jobs are perceived to provide a better stability, lesser travel, regular working hours, leave benefits and a secure work environment.

Inspite of the fact that females of the family working along with the males of the family, yet family issues are still seen a female problem. Harvard Business Professor Boris Groysberg and research associate Robin Abrahams looked at the interview of $4000 \mathrm{c}$-suite executives out of which $44 \%$ executives were female and men and women having the same job title. The major difference between the two is how they frame their work life conflicts. Men always think themselves as breadwinners leaving all the family problems on the female partner. As per the article, $88 \%$ of the men are married compared with $70 \%$ of the women. Out of them $60 \%$ of the 
men have spouses who either don't work full time or stay at home. This helps the man to take any help from the spouse where as in case of females, by paying they can get all sort of help but wont able to spend their time with kids. This emotional guilt insists them to leave their job. Male executives feel that their role in the family is providing them the amenities they need and are not concerned with any other family issues.

\section{Results:}

Work life is the satisfactory level of involvement between the multiple roles in a person's life. Earlier the role of a woman was limited to her household work but now active involvement in jobs is pushing them in a condition where they need to maintain their work life balance. To maintain work life balance, they need family as well as organizational support. Family Support is the support to women from her family members, spouse, any other support in household work. Various studies proved that non fulfillment of Family Support may lead to a woman in stress that also affects her working life. In the current study, perception of Public and Private sector banks employees towards Family Support are considered that helps them to achieve better work life balance.

Table 4.1: Family Level factors that support to maintain Work Life balance in Public Sector employee (percentage in paranthesis)

\begin{tabular}{|l|l|c|c|c|c|c|}
\hline S.no & Factors & $\begin{array}{l}\text { Strongly } \\
\text { Disagree }\end{array}$ & Disagree & Neutral & Agree & $\begin{array}{l}\text { Strongly } \\
\text { Agree }\end{array}$ \\
\hline 1 & Family Supports in the house work & - & - & $5(2.0)$ & $98(39.2)$ & $147(58.8)$ \\
\hline 2 & $\begin{array}{l}\text { Shared responsibilities } \\
3\end{array}$ & $6(2.4)$ & - & $9(3.6)$ & $152(60.8)$ & $83(33.2)$ \\
\hline 4 & $\begin{array}{l}\text { Full time servant available for work } \\
\text { at home. }\end{array}$ & $14(5.6)$ & $43(17.2)$ & $43(17.2)$ & $70(28.0)$ & $80(32.0)$ \\
\hline & $\begin{array}{l}\text { Elders are present at home to look } \\
\text { after the dependents }\end{array}$ & $8(3.2)$ & $26(10.4)$ & $18(7.2)$ & $67(26.8)$ & $131(52.4)$ \\
\hline 5 & $\begin{array}{l}\text { Dependent care facilities available } \\
\text { at home }\end{array}$ & $5(2.0)$ & $14(5.6)$ & $6(2.4)$ & $91(36.4)$ & $134(53.6)$ \\
\hline
\end{tabular}

Table 4.1 shows the perception of Public sector banks employees towards family factors that have influence on the work life balance. Five factors are considered to examine the impact of family factors on work life balance. When respondents are asked about the family support in the housework then $58.8 \%$ of the respondents strongly agree that family support helps them to achieve work life balance, for shared responsibilities $60.8 \%$ agree that it helps to achieve work life balance. In regard to full time servant, $32 \%$ strongly agree and $28 \%$ agree where as $17.2 \%$ disagree that it helps in achieving work life balance. $52.4 \%$ strongly agree and $26.8 \%$ agree where as $10.4 \%$ disagree that presence of elders at home helps them to achieve work life balance. Apart from elder's presence, 53.6\% strongly agree that dependent care facilities help in achieving work life balance. 
Table 4.2: Family Level factors that support to maintain Work Life balance in Private Sector bank employee (percentage in paranthesis)

\begin{tabular}{|c|c|c|c|c|c|c|}
\hline S.no & Factors & $\begin{array}{l}\text { Strongly } \\
\text { Disagree }\end{array}$ & Disagree & Neutral & Agree & $\begin{array}{l}\text { Strongly } \\
\text { Agree }\end{array}$ \\
\hline 1 & Family supports in house work & $6(2.4)$ & $2(.8)$ & $6(2.4)$ & $76(30.4)$ & $160(64.4)$ \\
\hline 2 & Shared responsibilities & $5(2.0)$ & & $12(4.8)$ & $154(61.6)$ & $79(31.6)$ \\
\hline 3 & $\begin{array}{l}\text { Full time servant available for work } \\
\text { at home. }\end{array}$ & $16(6.4)$ & $28(11.2)$ & $50(20.0)$ & $73(29.2)$ & $83(33.2)$ \\
\hline 4 & $\begin{array}{l}\text { Elders are present at home to look } \\
\text { after the dependents }\end{array}$ & $5(2.0)$ & $14(5.6)$ & $\begin{array}{c}29 \\
(11.6)\end{array}$ & $62(24.8)$ & $140(56.0)$ \\
\hline 5 & $\begin{array}{l}\text { Dependent care facilities available } \\
\text { at home }\end{array}$ & & $12(4.8)$ & $6(2.4)$ & $84(33.6)$ & $148(59.2)$ \\
\hline
\end{tabular}

Table 4.2 shows family factors that have influence on the work life balance of women employees working in Private sector banks. Five factors are considered to examine the impact of family factors on work life balance. When respondents are asked about the Family Support in the housework then $64.4 \%$ of the respondents strongly agree that it helps them to achieve work life balance, for shared responsibilities $61.6 \%$ agree that it helps to achieve work life balance. In regard to full time servant, $33.2 \%$ strongly agree, and $29.2 \%$ agree for achieving work life balance. 56\% strongly agree that presence of elders at home helps them to achieve work life balance. Other facilities for dependent care show that $59.2 \%$ agree that it helps in achieving work life balance.

Table 4.3: Comparative Mean and Standard deviation of various dimensions of Family Support in Public and Private sector banks

\begin{tabular}{|l|r|r|r|r|}
\hline \multirow{2}{*}{} & \multicolumn{2}{|c|}{ Public } & \multicolumn{2}{c|}{ Private } \\
\cline { 2 - 5 } & Mean & Std. Deviation & \multicolumn{1}{c|}{ Mean } & Std. Deviation \\
\hline Family supports in the house work & 4.57 & .535 & 4.53 & .797 \\
\hline Shared responsibilities & 4.22 & .732 & 4.21 & .709 \\
\hline Full time servant available for work at home. & 3.64 & 1.248 & 3.72 & 1.217 \\
\hline $\begin{array}{l}\text { Elders are present at home to look after the } \\
\text { dependents }\end{array}$ & 4.15 & 1.133 & 4.27 & 1.005 \\
\hline Dependent care facilities available at home & 4.34 & .923 & 4.47 & .767 \\
\hline
\end{tabular}

Table 4.3 presents a comparative statement of mean and standard deviation values among the respondents of Public sector banks and Private sector banks. From the table it can be concluded that mean value of Public sector banks respondents are more in most of the cases. 


\section{Table 4.4: Organizational Level factors that can support to maintain Work Life balance in Public sector banks employee (percentage in paranthesis)}

\begin{tabular}{|l|c|c|c|l|l|}
\hline Factors & $\begin{array}{l}\text { Strongly } \\
\text { Disagree }\end{array}$ & Disagree & Neutral & Agree & $\begin{array}{l}\text { Strongly } \\
\text { Agree }\end{array}$ \\
\hline Top Management supports at work & - & $2(.8)$ & $25(10.0)$ & $105(42.0)$ & $118(47.2)$ \\
\hline Co-workers are supportive & $1(.4)$ & $5(2.0)$ & $8(3.2)$ & $172(68.8)$ & $64(25.6)$ \\
\hline Flexible working hours & $11(4.4)$ & $31(12.4)$ & $15(6.0)$ & $108(43.2)$ & $85(34.0)$ \\
\hline Flexible work location & $7(2.8)$ & $29(11.6)$ & $22(8.8)$ & $82(32.8)$ & $110(44.0)$ \\
\hline Compressed working week & $4(1.6)$ & $24(9.6)$ & $36(14.4)$ & $77(30.8)$ & $109(43.6)$ \\
\hline Organisational Change & $3(1.2)$ & $28(11.2)$ & $35(14.0)$ & $125(50.0)$ & $59(23.6)$ \\
\hline Telecommuting & - & $10(4.0)$ & $26(10.4)$ & $117(46.8)$ & $97(38.8)$ \\
\hline Job sharing & $1(.4)$ & $13(5.2)$ & $41(16.4)$ & $76(30.4)$ & $119(47.6)$ \\
\hline Incentive for overtime & $14(5.6)$ & $10(4.0)$ & $16(6.4)$ & $95(38.0)$ & $115(46.0)$ \\
\hline Paid and unpaid leave provisions & $16(6.4)$ & $15(6.0)$ & $24(9.6)$ & $133(53.2)$ & $62(24.8)$ \\
\hline Part time work & $43(17.2)$ & $43(17.2)$ & $32(12.8)$ & $68(27.2)$ & $64(25.6)$ \\
\hline Provision for transfers & $1(.4)$ & $14(5.6)$ & $30(12.0)$ & $97(38.8)$ & $108(43.2)$ \\
\hline Ad hoc arrangements & $11(4.4)$ & $21(8.4)$ & $38(15.2)$ & $75(30.0)$ & $105(42.0)$ \\
\hline Provision for child care facilities & $14(5.6)$ & $18(7.2)$ & $9(3.6)$ & $130(52.0)$ & $79(31.6)$ \\
\hline Travel time & $1(.4)$ & $2(.7)$ & $23(9.2)$ & $100(40.0)$ & $117(46.8)$ \\
\hline
\end{tabular}

Organizational Factors are those factors that are related to the organization. To achieve work life balance, only family level factors are not sufficient but the work related problems can be solved if the organization will also adopt work life balance policies. To know the perception of the Public sector banks employees for organizational factors, 15 factors are considered. The respondents are asked about the various organizational factors that they perceive support them to achieve work life balance. $47 \%$ of the respondents strongly agree and $42 \%$ agree that top management support helps them to achieve work life balance. $68.8 \%$ agree that supportive co-workers are helpful for achieving work life balance. $43.2 \%$ agree and 34\% strongly agree that flexible working hours helps to achieve work life balance. For flexible work location, $44 \%$ strongly agree and $32.8 \%$ agree that it helps in achieving work life balance. In regard to compressed working week, $43.6 \%$ strongly agree, and $30.8 \%$ agree that it helps in achieving work life balance. $50 \%$ agree where as $11.2 \%$ disagree that organizational change is an important factor that affects work life balance. For telecommuting, $46.8 \%$ agree and $38.8 \%$ strongly agree that it helps them to achieve work life balance. In regard to job sharing, $47.6 \%$ strongly agree, that it helps to achieve better work life balance. Incentive for overtime shows that $46 \%$ strongly agree for better work life balance. 53.2\% agree that paid and unpaid leave provisions helps in achieving work life balance. For Part time work, 27.2\% agree and $25.6 \%$ strongly agree where as $17.2 \%$ disagree and strongly disagree that it helps to achieve work life balance. Provision for transfers show that $43.2 \%$ strongly agree $38.8 \%$ agree for achieving work life balance. For Ad hoc arrangements, $42 \%$ strongly agree and 30\% agree that it helps in achieving work life balance. Provision for child care facilities show that $52 \%$ agree that it is an 
important factor for achieving work life balance. Travel time shows $46.8 \%$ respondents strongly agree $40 \%$ agree that it helps in achieving work life balance.

Table 4.5: Organizational Level factors that can support to maintain Work Life balance in Private sector banks employee (percentage in paranthesis)

\begin{tabular}{|l|c|c|c|c|l|}
\hline Factors & $\begin{array}{l}\text { Strongly } \\
\text { Disagree }\end{array}$ & Disagree & Neutral & Agree & $\begin{array}{l}\text { Strongly } \\
\text { Agree }\end{array}$ \\
\hline Top Management supports at work & - & $1(.4)$ & $13(5.2)$ & $99(39.6)$ & $137(54.8)$ \\
\hline Co-workers are supportive & $1(.4)$ & $5(2.0)$ & $8(3.2)$ & $172(68.8)$ & $64(25.6)$ \\
\hline Flexible working hours & $7(2.8)$ & $36(14.4)$ & $9(3.6)$ & $108(43.2)$ & $90(36.0)$ \\
\hline Flexible work location & $8(3.2)$ & $28(11.2)$ & $12(4.8)$ & $68(27.2)$ & $134(53.6)$ \\
\hline Compressed working week & $3(1.2)$ & $11(4.4)$ & $53(21.2)$ & $66(26.4)$ & $117(46.8)$ \\
\hline Organisational Change & $2(.8)$ & $28(11.2)$ & $38(15.2)$ & $128(51.2)$ & $54(21.6)$ \\
\hline Telecommuting & - & $9(3.6)$ & $23(9.2)$ & $111(44.4)$ & $107(42.8)$ \\
\hline Job sharing & - & $11(4.4)$ & $26(10.4)$ & $71(28.4)$ & $142(56.8)$ \\
\hline Incentive for overtime & $24(9.6)$ & $5(2.0)$ & $20(8.0)$ & $79(31.6)$ & $122(48.8)$ \\
\hline Paid and unpaid leave provisions & $17(6.8)$ & $19(7.6)$ & $31(12.4)$ & $115(46.0)$ & $68(27.2)$ \\
\hline Part time work & $50(20.0)$ & $19(7.6)$ & $43(17.2)$ & $76(30.4)$ & $62(24.8)$ \\
\hline Provision for transfers & $2(.8)$ & $16(6.4)$ & $49(19.6)$ & $64(25.6)$ & $119(47.6)$ \\
\hline Ad hoc arrangements & $2(.8)$ & $19(7.6)$ & $42(16.8)$ & $52(20.8)$ & $127(50.8)$ \\
\hline Provision for child care facilities & $22(8.8)$ & $10(4.0)$ & $17(6.8)$ & $118(47.2)$ & $83(33.2)$ \\
\hline Travel time & $4(1.6)$ & $8(3.2)$ & $26(10.4)$ & $66(26.4)$ & $146(58.4)$ \\
\hline
\end{tabular}

Table 4.5 shows the perception of the Private sector banks employees for organizational factors. The respondents are asked about the various organizational factors that they perceive support them to achieve work life balance. $54.8 \%$ of the respondents strongly agree that top management support helps them to achieve work life balance. $68.8 \%$ agree that supportive co-workers are helpful for achieving work life balance. $43.2 \%$ agree and $36 \%$ strongly agree that flexible working hours helps to achieve work life balance. For flexible work location, $53.6 \%$ strongly agree that it helps in achieving work life balance. In regard to compressed working week, $46.8 \%$ strongly agree that it helps in achieving work life balance. $51.2 \%$ agree that organizational change is an important factor that affects work life balance. For telecommuting, $44.4 \%$ agree and $42.8 \%$ strongly disagree that helps them to achieve work life balance. In regard to job sharing, 56.8\% strongly agree that it helps to achieve better work life balance. Incentive for overtime shows that $48.8 \%$ strongly agree for better work life balance. $46 \%$ agree that paid and unpaid leave provisions helps to achieve better life balance. For Part time work, $34 \%$ agree that it helps to achieve work life balance. Provision for transfers shows that $47.6 \%$ strongly agree for achieving work life balance. For Ad hoc arrangements, 50.8\% strongly agree that it helps in achieving work life balance. Provision for child care facilities show that $47.2 \%$ agree that it is an important factor for achieving work life balance. Travel time shows $58.4 \%$ respondents strongly agree that it helps in achieving work life balance. 
Table 4.6: Comparative Mean and Standard deviation of various dimensions of organizational support in Public and Private Sector Banks

\begin{tabular}{|l|c|c|c|c|}
\hline \multirow{2}{*}{} & \multicolumn{2}{|c|}{ Public } & \multicolumn{2}{c|}{ Private } \\
\cline { 2 - 5 } & Mean & SD & Mean & SD \\
\hline Top Management supports at work & 4.36 & .692 & 4.49 & .616 \\
\hline Co-workers are supportive & 4.17 & .613 & 4.20 & .601 \\
\hline Flexible working hours & 3.90 & 1.135 & 3.95 & 1.108 \\
\hline Flexible work location & 4.04 & 1.117 & 4.17 & 1.139 \\
\hline Compressed working week & 4.05 & 1.053 & 4.13 & .975 \\
\hline Organisational Change & 3.84 & .953 & 3.82 & .926 \\
\hline Telecommuting & 4.20 & .783 & 4.26 & .772 \\
\hline Job sharing & 4.20 & .921 & 4.38 & .842 \\
\hline Incentive for overtime & 4.15 & 1.082 & 4.08 & 1.229 \\
\hline Paid and unpaid leave provisions & 3.84 & 1.067 & 3.79 & 1.129 \\
\hline Part time work & 3.27 & 1.447 & 3.32 & 1.441 \\
\hline Provision for transfers & 4.19 & .883 & 4.13 & .994 \\
\hline Ad hoc arrangements & 3.97 & 1.144 & 4.06 & 1.182 \\
\hline Provision for child care facilities & 3.97 & 1.071 & 3.92 & 1.162 \\
\hline Travel time & 4.28 & .856 & 4.36 & .927 \\
\hline
\end{tabular}

Table 4.6 presents a comparative statement of mean and standard deviation values among the Public and Private sector banks women employees. From the table it cannot be concluded that any one type of population scored more than the other. However, it was found that mean value of Public sector banks employees are least in most of the cases.

\section{Results of One Way ANOVA:}

Results of one-way ANOVA conducted on data collected from Public sector banks employees and Private sector banks employees regarding their perception towards various components of Family Support and Organisational Support. The ANOVA was conducted to find out if there exists some significant difference among the employees related to their demographic profile. The result shows that in Public sector banks, Family Support in house work and shared responsibilities are significant factors on the basis of education. Based on designation, dependent care facilities shows significant difference. On the basis of experience, Family support in housework shows the significant difference. And on salary basis, dependent care facilities show significant difference. In regard to Private sector banks, the factor that shows the significant difference is full time servant available at home based on education and family supports in house work on the basis of family type. For Organisational Support, in Public sector banks the factors that shows the significant difference are provision for transfers on the basis of education, top management support at work on the basis of designation, provision for transfers on the basis of experience, flexible work location on the basis of salary, ad hoc arrangements on the basis of marital status, compressed working week, provision for transfers and travel time on the basis of family type. In Private sector banks, the factor that shows the significant difference is travel time on the basis of designation and organisational change on the basis of marital status. 


\section{References:}

$>$ Hudson (2005). The case for Work life balance: Closing the gap between policy and Practice. 20:20 Series, pp-1-36.

$>$ Matuska, K. and Christiansen, C. (2009). Life Balance: Multidisciplinary Theories and Research. Bethesda, MD: AOTA Press/Slack Publishers.

$>$ Valcour, M.(2007). Work bases resources as moderators of relationship between work hours and satisfaction with work life balance. Journal of Applied Psychology, Vol.- 92, No-6, pp-1512-1523.

$>$ Clutterbuck, D. (2003). Managing work-life Balance: A guide for HR in achieving organisational and individual change. London: Chartered Institute of Personnel and Development.

$>$ Guest, D.E. (2002). Perspectives on the study of work life balance. Discussed paper prepared for the 2001 ENOP Symposium, Paris, March, 29-31.

$>$ Aziz, S., Cunningham, J. (2008). Workaholism, work stress, work-life imbalance: exploring gender's role, Gender in Management. An International Journal Vol. -8, pp553-566. 